\title{
Regulatory and Legal Issues of Environmental Risk Management for Enterprises of the Ural Federal District and Kemerovo region
}

\author{
Igor Yazhlev ${ }^{1, *}$, Tatiana Boravskaya $^{2}$, and Yulia Korneeva ${ }^{3}$ \\ ${ }^{1}$ Environmental insurance association, Institute of advanced studies "Arsenal" 125047, Tverskaya \\ Yamskaya 3 str. 15/14, Moscow, Russia \\ ${ }^{2}$ Federation Council of the Federal Assembly of the Russian Federation 107031, Bolshaya Dmitrovka \\ str. 26, Moscow, Russia \\ ${ }^{3}$ CJSC "Green Valley» 620102, Belorechenskaya str. 17-3, Ekaterinburg, Russia
}

\begin{abstract}
There are environmental risks in the process of economic activity of enterprises that threaten the financial stability of enterprises and the rights of citizens to a favorable habitat. The introduction of environmental insurance will speed up and streamline the process of environmental recovery and create a mechanism for guaranteed elimination of environmental damage under these conditions. The article is based on the analysis of Russian and foreign experience of environmental risk management in the production of products and services. Environmental insurance is one of the most universal and widespread instruments in this field. The problems of legislative and methodological issues of the introduction of this kind of insurance in the Russian Federation are considered.
\end{abstract}

\section{Introduction}

The analysis of the provisions of the environmental and insurance legislation shows the following:

- environmental risk-probability of occurrence of the event having adverse consequences for the natural environment and caused by negative impact of economic and other activity, emergency situations of natural and technogenic character;

- the insurance risk is the expected event, in case of which the insurance is carried out. The event considered as insurance risk, should possess signs of probability and accident of its approach.

\section{Materials and Methods}

The following risk groups in the field of environmental protection and nature management can be covered by insurance coverage:

- risks of environmental liability;

\footnotetext{
*Corresponding author: hoved@yandex.ru
} 
- risks of damage to natural resources for which there is a right of ownership, use or disposal;

financial risks of enterprises that are users of natural resources or carry out environmentally hazardous activities, in order to protect their property interests;

- risks of liability of enterprises for non-performance (improper performance) of obligations under agreements of nature management.

In the Russian Federation the foundations for development of environmental insurance are laid by the Federal law of 10.01.2002 No. 7-FZ "On environmental protection", and also by the Model law "On environmental insurance" (the resolution of MPA CIS of 18.04.2014 No. 40-10) which is the advisory act for all states - participants of the Commonwealth of independent States.

In this regard, it should be noted, that in countries where the negative impact on natural resources is intense, national legislation establishing the rules of compulsory environmental insurance has been adopted: the law of the Republic of Azerbaijan "On compulsory environmental insurance" (2002), the Law of the Republic of Kazakhstan "On compulsory environmental insurance" (2005). In China, one of our main partners in the Shanghai cooperation organization, the law of the People's Republic of China " The Environmental protection Act " came into force on January 1, 2015, where Art. 52 establishes the obligation of state bodies to stimulate the participation of enterprises in environmental insurance. There is an experience of compulsory environmental insurance in the EU and the USA.

\section{Results and Discussion}

Russia has a positive experience of compensation of environmental damage and providing financial guarantees in case of drawing such damage. There is a law enforcement practice of the following laws: "On space activity" of 29.11.1996 No. 147-FZ; "The code of trade navigation of the Russian Federation" of 30.04.1999 No. 81-FZ; "On the continental shelf of the Russian Federation" of 30.11.95 No. 187-FZ; "On internal sea waters, the territorial sea and the adjacent zone of the Russian Federation" of 31.07. 98g. No. 155-FZ.

At the same time, the fragmentation, insufficient legislation and methodological support still do not make it possible to turn environmental insurance into a versatile and promising tool for ensuring environmental safety and guaranteed compensation for environmental damage. This is confirmed by the following.

The existing wording of Art. 18 of the Federal law "On environmental protection" establishes the only form of compulsory environmental insurance in the form of compulsory state environmental insurance. This means the implementation of environmental insurance at the expense of funds allocated from the relevant budgets (Art. 969 of the civil code). Therefore, it is necessary to bring Art. 18 "On environmental insurance" of the Federal law "On environmental protection" in line with the current regulations, law enforcement practice and foreign experience.

The results of the implementation of the Federal law № 116 "On industrial safety of hazardous production facilities" and the analysis of foreign experience reveals difficulties with the regulation of environmental damage in the framework of the policies of the General civil liability and commercial liability. Different nature of risks and damages, different industrial and environmental legislation, different methodological support of risks and damages assessment involves the development and application of special, separate types of coverage.

Environmental risks are not taken into account in the operation of facilities that have a negative impact on the environment, referred by The government of the Russian Federation to objects of 1-st,2,3,4-th categories or, in accordance with The government Decree of 
24.12.2014 g. №2674-R, to activities included in the list of areas of application of the best available technologies (BAT). Many objects of the 1st and 2nd categories are not subject to the Federal law of 27.07.2010 № 225-FZ "On compulsory insurance of civil liability of the owner of a dangerous object." Therefore, it is necessary to develop and adopt in the prescribed manner the Federal law "On compulsory insurance of liability for damage to the environment caused by the subject of economic and other activities" taking into account the realities associated with the introduction of BAT.

In this regard, it is necessary to consider separately the insurance problems in the field of waste management and risks in the field of redevelopment and cleaning up of brownfields. Prevention and compensation of environmental damage is the main purpose of insurance of solid waste landfills. This approach should be based on close cooperation between the insurers, the insured and the reinsurers. For a solid waste landfills operator it is very important that the insurance act should be in effect both in the early stages of its existence and after the landfill is closed, but the requirements for maintenance of the landfill still work. For insurance purposes, it is essential to conduct a comprehensive assessment of the nature and content of the risks of the management of landfill sites. The risk assessment should show weak places in the technical and organizational conditions of the landfill operation from the point of view of the insurer and the reinsurer.

The possibilities of the mechanism of so-called "imputed environmental insurance" are not used. This kind of insurance provides that the insurers (users of natural resources) have two options: either to insure by overpaying the premium, or to reduce their risks, which leads to a reduction in the tariffs. Thus, "imputed environmental insurance" in fact still forces the enterprise to compulsory environmental insurance to protect itself against environmental risks. This, in turn, increases the liability of business for compensation for environmental damage and does not allow activities without financial guarantees.

First of all the imputed kinds of insurance should be:

- liability insurance of mineral resources users for non-performance (improper performance) of obligations under environmental management agreements, including insurance of the risk of non-performance by the mineral resources user of their contractual obligations for the conservation and liquidation of mines, wells and other underground structures;

- liability insurance of water users for non-performance or improper performance of obligations under the agreement on the use of water resources;

- liability insurance of forest users for non-performance or improper performance of obligations under the agreement of use of a site of forest Fund;

- liability insurance of land users for non-performance or improper performance of obligations under the agreement on the use of land;

- insurance of forest areas and protected areas (state nature reserves or national parks) from fires and other risks.

The obstacle to the development of environmental insurance is the period limited by article 966 of "The Civil code of Russian Federation" for claims related to property insurance, which includes also the liability insurance for injury and liability insurance under the contract. Therefore, it is necessary to amend this article and establish a norm that allows insurers to file claims within the time limits established by Federal environmental laws or other regulatory legal documents of the Russian Federation in the field of environmental management and protection.

Almost never used such an effective kind of insurance as a mutual insurance. For realization of this kind of insurance in Russia the Federal law of December 4, 2007 No. 286-FZ "On mutual insurance" was adopted. The organizational form of implementation of this kind of insurance is the mutual insurance companies, which is a full participant of the insurance market. 
In this regard, the mutual insurance companies have a number of advantages, the main of which are the following:

- the mutual insurance companies take into account the real interests of insureds and offer the necessary amount of insurance coverage (for risks) in contrast to commercial insurers, limiting insurance coverage, dictated by foreign reinsurers or raising the price of the insurance service;

- they form their reserves and funds, the expenditure of which is determined by the members of the mutual insurance company, including the direction of resources for the implementation of preventive measures that insurance companies are not able to implement because of Russian tax legislation;

- they have an opportunity to make timely decisions and to finance the actions directed on reduction of consequences of the insured event occurred for the purpose of minimization of destructive consequences and future insurance payments;

- the members of mutual insurance company are both insureds and insurers, and directly control the activities of their established company.

The members of the company have the purpose of risk-sharing and redistribution of the company's funds in favor of those members who incur losses due to the occurrence of an insured event in respect of their assets on pre-agreed terms. For these purposes, they decide to combine their property in the amount of pre-calculated amounts of insurance premiums.

Given the long-term cooperation between the cities of the Sverdlovsk region and the Republic of China, it is advisable to briefly consider the Chinese experience in the development of environmental insurance in order to develop joint strategies in this area.

In 2007 the State environmental protection administration of China (SEPA) and the China insurance regulatory commission (CIRC) started a pilot project for introduction of environmental insurance in the voluntary form, and also in combination of voluntary and compulsory forms at the enterprises of chemical, metallurgical and food processing industries. In this period, they managed to achieve some success: the number of insurers and insureds increased, the variety of insurance products increased, methodological support and regulatory framework develops. At the same time, Chinese environmentalists note insufficiency of legislative and methodological support, the limitations of the proposed insurance products, lack of understanding of the goals of this kind of insurance by insurers and insureds.

SEPA and CIRC have jointly issued a set of regulatory documents:

- "Technical guidance on environmental risk assessment and classification methods for chlor-alkali plants" (January 2010).);

- "Guidelines for the development of compulsory insurance of civil liability for environmental pollution" (January 2013);

- "Recommendations on risk assessment of sudden environmental incidents at the enterprise" (April 2014), etc.

There were also formed regional models for the development of environmental insurance using various incentive measures. For example, number of provinces offer subsidies in the event of the acquisition of an environmental insurance policy. On the one hand, the insureds can receive subsidies to pay the insurance premium. For high-tech enterprises, it is up to $70 \%$, for other industries up to $50 \%$. On the other hand, insurance companies that cover environmental liability may also receive tax incentives and subsidies.

There have been taken measures to promote environmental insurance at the legislative level. Thus, article 52 of "The Environmental protection Act", which came into force on 1 January 2015, determined that the state should encourage the introduction of liability insurance for environmental pollution. The 51st article of "The Taihu Management Regulation", the largest freshwater lake in China, establishes that the state should encourage enterprises in the Taihu lake basin to insure liability for environmental pollution. 
At the regional level, in several provinces where pilot projects are being implemented and the need to encourage the introduction of environmental insurance is determined by local environmental legislation. In addition, the state bodies develop tax incentives for the introduction of environmental insurance, which is also offered to insurance companies covering environmental risks.

At the same time, Chinese environmentalists note that the current methodological support for the risk assessment of environmental damage is not standardized, does not meet modern requirements and is a deterrent to the introduction of environmental insurance in China.

As a kind of insurance the environmental insurance, which simultaneously takes into account the provisions of environmental, natural resource, insurance and industry legislation, should have a developed methodological support for the assessment of environmental damage and risks, as well as a developed market of insurance products. This requires the environmental state authorities that exercise public administration in the field of environmental protection to develop and implement administrative, organizational, economic and other measures for effective implementation environmental insurance.

\section{Conclusion}

The regional pilot projects (e.g. in the Kemerovo region and Ural Federal District) of voluntary environmental insurance should be aimed at development of the mechanism of environmental insurance, environmental legislation and methodological support, common approaches to environmental insurance, assessment of environmental damage, accumulation of statistical data allowing to estimate reliably probability of occurrence of an insured event and estimate both the size of the insurance premium and the amount of insurance coverage, development of methods for informing and encouraging insureds to conclude voluntary environmental insurance contracts.

\section{References}

1. C. Bell, Policy Advisor, Non-life Insurance (European Commission, Brussels, 2014)

2. H. Guo, International Journal of Business Administration, 7:1, 45 (2016)

3. T. Bie, B. Wang, The Environment Economy, 7, 78-87 (2014)

4. Evaluating the experience gained in the ELD Implementation (European Commission, Brussels, 2013)

5. A. L. Jia, Journal of Zhejiang Forestry University, 4, 145-158 (2008)

6. J. Z. Ren, Jilin University, 7, 18-25 (2014)

7. Market perspective United States insurance market report 2013 (Marsh and McLennan companies, New York, 2013)

8. G. Y. Zhou, L. H. Wan, Insurance Research, 56:7, 1302 (2013)

9. N. V. Kovalenko, T. V. Boravskaya, I. K. Yazhlev, Ecology of production, 8, 76-81 (2013) 